\title{
Content Analysis of Government Financial Statement
}

\author{
Sri Rahayu * \\ Accounting Department, Jambi University, Pinang Masak Mendalo Indah Campus, \\ Muaro Jambi, Indonesia \\ Yudi \\ Accounting Department, Jambi University, Pinang Masak Mendalo Indah Campus, \\ Muaro Jambi, Indonesia \\ Rahayu \\ Accounting Department, Jambi University, Pinang Masak Mendalo Indah Campus, \\ Muaro Jambi, Indonesia
}

Jambi University finances the research (Sponsoring information)

\section{Abstract}

This study aims to analyze the condition of the central government's financial statements. Researchers used content analysis with three stages, namely open, axial and selective coding. The results showed that the Covid 19 pandemic had an impact on the financial condition of the central government both in terms of revenues and expenditures. Revenue from the tax and non-tax sectors experienced a significant decline in 2020. The type of revenue that experienced an increase only came from grants. From the output side, several types of expenditure have shifted to be allocated to spending for the prevention and prevention of the spread of the Covid 19 pandemic. Based on the balance sheet, it can be seen that the total assets and liabilities increased from 2016-2020, but equity decreased in 2020. Overall, the quality of the central government's financial reports has been good, it has been proven that since 2016 it has continued to receive unqualified opinions. The quality of the financial reports of ministries and institutions also continues to improve, as evidenced by the increase in the number of unqualified opinions. Further researchers can develop other research methods such as quantitative or collect additional data through interviews and focus group discussions.

Keywords: Audit Opinion, Financial Statements, Content Analysis, Government

DOI: $10.7176 /$ RJFA/13-2-08

Publication date: January $31^{\text {st }} 2022$

\section{Introduction}

Government financial management reform has always been an interesting topic to discuss, because it involves people's lives at large. In Indonesia, the reform of financial management, both from the side of budgeting to financial reporting, began with the reform in 1998. The government is carrying out its activities following the new public management (NPM) pattern. Experts see that NPM will be able to solve various problems in government organizations so that they run their operations like private organizations (Brown, Waterhouse, \& Flyn, 2003). Christensen and Lægreid (2014) even state that NPM is also a concept that focuses on increasing the response of public institutions to society, efficiency and accountability as well as government performance.

Accrual-based financial reports are one form of implementation of NPM (Harun et al., 2013). The Indonesian government has implemented accrual-based financial reports effective since 2016 for 2015 financial statements. The purpose of implementing the accrual basis is to provide more useful information in decision-making and evaluation. The government accounting standards are intended to facilitate public sector accountability, managerial performance, transparency, and inter-generational equity NPM (Harun et al., 2013). Financial reports are one of the information that can be used by the public and other stakeholders to assess government performance.

The government must present quality financial reports. Audit opinion can be one of the benchmarks of the fairness of the financial statements presented by the government. In addition to opinions, internal auditors will also issue results of examinations related to the implementation of internal controls related to financial reporting and compliance with laws and regulations. The auditor not only presents the results of the examination but also provides recommendations. Recommendations are given with the aim that the improvement process is carried out so that the findings of the same examination are not repeated in the next period. Follow-up on audit findings will also continue to be monitored as a form of commitment to improvements that have been made by the government as the auditee.

Studies regarding the performance and health of government organizations by using data based on financial reports, many have done such as Ritonga et al.,(2012); Rahayu et al., (2021). Studies on these studies focus on how to measure government performance and health as measured by financial ratios. The financial ratios used include the ratio of financial independence, solvency ratio, liquidity ratio, fiscal decentralization ratio, and other 
ratios. Other studies on the process of applying the accrual basis in the preparation of government financial statements in Indonesia have also become the focus of several studies, including Harun et al., (2012a); Harun et al., (2012b), and Harun et al., (2013).

This research is different from previous research. This study aims to conduct a study on the condition of the government's financial statements. The study was carried out on the financial statements, not only in terms of the development of the financial position but also the condition of the internal control system and compliance with laws and regulations. The results of this study are expected to provide a more comprehensive picture of the state of the government's financial statements.

\section{Literature Review}

\subsection{New Public Management and its Consequences for government financial reports}

In the 1980s the concept of new public management began to be applied in England, New Zealand, and the United States (Puspawati, 2016). This concept then began to be applied in Indonesia when the decentralization system was implemented starting in the late 1990s. Decentralization in government means delegating some responsibilities and authorities including financial management to each region. Decentralization emerged after the government reform. The reforms that occur are not only institutional reforms, but also public sector management reforms (Anggraini \& Puranto, 2010). NPM is seen as the right concept to use as the basis for reforming the field of government management.

Decentralization is one of the main characteristics of NPM (Polidano, 1999) with a claim to efficiency and effectiveness. NPM wants government agencies to operate like private organizations. If traced, one of the main theoretical bases of NPM is the public choice theory (PCT) (Gruening, 2001; Tolofari, 2005). PCT greatly influences the theory and practice of public policy. Individuals are considered rational (Gruening, 2001; Andrianto \& Irianto, 2008) in making choices. According to PCT, political actors will act rationally both in their efforts to gain power and maintain existing power (Andrianto \& Irianto, 2008). Bureaucratic organizations are inefficient in using resources because they still use traditional budgeting and there is no evaluation with a market system (Gruening, 2001).

NPM works guided by 5 important things, namely: first, a decentralized system which is intended to bring decision-making closer to the people who want to be served; second, Privatization which is intended to transfer the allocation of goods and services from the government to the private sector; third, Downsizing is carried out by reducing and simplifying the number and scope of the organization and governance structure; fourth, debureaucratization is carried out by restructuring the government bureaucracy which will emphasize results rather than process; and fifth, Managerialism which is the adoption of a private way of working in government organizations (Puspawati, 2016).

The development of the NPM concept was followed by the abandonment of traditional budgets by public sector organizations and shifting to adopting performance-based budgeting (Yuwono et al., 2008). NPM has the characteristics of market mechanisms, privatization, performance measurement, and accountability. NPM is changing all sectors including education services. The application of local management of the school resulted in the increasing influence of stakeholders in the daily life of the school, while the intimacy of the academic world was reduced. NPM brings a political ideology with a background in business applications in educational administration, the application of managerial systems in educational institutions, and the enforcement of standards and accountability (performativity). (Tolofari, 2005).

Decentralization is one of the main characteristics of NPM (Polidano, 1999) with a claim to efficiency and effectiveness. NPM wants government agencies to operate like private organizations. The main criticisms of public sector organizations, especially the government, are often judged to be of low quality, unproductive, minimal innovation and creativity (Mahmudi, 2016), large in size, and inefficient (Brown et al., 2003; Mahmudi, 2016), low human resource capacity (Polidano, 1999; Guess, 2005) and an alarming level of corruption (Polidano, 1999). This criticism is also the starting point for thinking about public sector financial reform in America (Gruening, 2001).

One consequence of the implementation of NPM is the application of performance-based budgeting (PBB) in all public sector organizations including schools. With the issuance of Government Regulation (PP) No. 105 of 2000 concerning Regional Financial Management, began an era in the preparation of performance budgets in Regional Governments (Yuwono et al., 2008). Furthermore, the implementation of performance-based budgeting nationally has been launched since the enactment of Law no. 17 of 2003 concerning state finances and Law no. 1 of 2004 concerning the state treasury.

The ratification of Law No. 17 of 2003 resulted in all government organizations at the central and regional levels having to implement an accrual reporting system called the 'cash to accrual system'. Government Accounting Standards are regulated in Government Regulation no. 24 of 2005, subsequently revised in Government Regulation no. 71 of 2010, regulates the types of reports and accounts that need to be prepared by government organizations in the country. Government Regulation No. 71 of 2010 has required the application of accruals by all government 
agencies (Harun, An \& Kahar, 2013). Therefore, NPM has consequences on the preparation of accrual-based government financial statements.

\subsection{Legitimacy Theory and Financial Statement}

Institutional theory can also be divided into two groups, namely old institutional sociology (OIS) and new institutional sociology (NIS) (DiMaggio and Powell, 1991; Selznick, 1996). These two groups have in common is the view that the actors in the organization are not completely rational. Both also see the relationship between the organization and its environment and wish to reveal the reality of inconsistencies in the formal appearance of the organization (Dimaggio \& Powell, 1991). Environmental aspects are used by the organization as part of its rituals. Both have differences which can be seen in table 2.1.

The basic difference between OIS and NIS lies in the focus of the analysis, the approach to the environment, the view of conflict and change, and the description of individual actions. (DiMaggio and Powell, 1991). OIS views that change is carried out by the organization because the organization's desire to change and change is natural to lead to a better condition. Change occurs because of the need to change, not because of external coercion or pressure. On the other hand, the NIS view that organizations change not necessarily to achieve efficiency, but for the sake of legitimacy and homogenization within similar groups. OIS is very interested in the coherence and strength of the existence of an institution in the organization. NIS not only pays attention to this,

Public welfare is a mandate carried out by the central and regional governments in accordance with the 1945 Constitution. In carrying out this mandate, the Indonesian government has made changes in various aspects. The management of government organizations is one of the targets of reform (Anggraini \& Puranto, 2010) and changes and improvements continue to be made. Legitimacy theory discusses views, perceptions, or assumptions in general how an entity's action is appropriate and appropriate with values, beliefs, and social norms as defined together (Patrick, 2012). Government organizations do many things to gain trust from the point of view of the agent and principal relationship. The government needs legitimacy from the community. If the complete legitimacy stage has been obtained, the stakeholders have entirely accepted the organization to receive support for the actions (Rahayu, 2016). The organization needs legitimacy to maintain its survival. Legitimacy is an essential factor in the life of an organization (Meyer and Rowan, 1977).

The accrual basis has long been used by private organizations. The accrual basis is a new institution for the government. Institutional theory can see this as an adaptation process that must be carried out by the government. The issuance of Government Accounting Standards through the issuance of government regulations is a form of government commitment to implement the new institution. The aim of implementing this new institution is good quality financial reports. The advantages of applying accruals include the financial information presented is more relevant for decision making. Quality financial reports will be one way for the government to convey information on financial conditions within a certain period.

Financial reports with good conditions will of course become legitimate for the government so that they can be legitimate for all stakeholders including the community. The government will get full support from the community so that community participation in the development process will be higher. This participation can be in the form of aspirations for development plans, suggestions for ideas, or being involved in the development process. In addition, participation can also take the form of supervising development activities carried out by the government. The community has the opportunity to oversee the implementation of government programs and activities because most development activities can be seen and felt by them directly.

One of the benchmarks of the quality of financial statements that can be used is the acquisition of an audit opinion. The Indonesian Audit Board (BPK) is the audit agency authorized to issue opinions on the results of audits of government financial statements in Indonesia. BPK will provide an opinion in the form of unqualified, qualified, unfair, and does not provide an opinion. BPK audits seven government financial reports consisting of balance sheets, budget realization reports, operational reports, excess budget balance reports, changes in equity reports, cash flow statements, and notes to financial statements.

\section{Research Method}

This study uses a qualitative research design. Qualitative research allows researchers to explore more deeply certain specific things (Creswell, 2012) which cannot necessarily be extracted from a quantitative approach. In the first stage, the researcher will collect and analyze the quantitative data derived from the document review. The data that will be used in this study are secondary data in the form of audited financial reports and reports on the results of the BPK examination. The research team will obtain this data from the website of the BPK (bpk.go.id). The financial statements reviewed are the audited financial statements of the Government of the Republic of Indonesia for 2018-2020.

Content Analysis Techniques (Content Analysis) is used as a technique for data analysis. Berelson (1952), one of the early originators of content analysis stated that this technique can be used to analyze and understand texts. The information obtained is described objectively, systemically, and quantitatively. Gunawan (2016) defines 
content analysis as a research method to determine the presence of words or concepts in a text or a set of text sequences. In working on the Content Analysis method, a coding mechanism is needed to classify the data to be analyzed (Saougi, Rahayu \& Machfudin, 2018). The stages of data analysis consist of open coding, axial coding, and selective coding.

Open coding is the process of sorting information from all data sources obtained from document reviews. In this stage, a researcher will identify categories and sub-categories from the information obtained from the data. Axial Coding is a process to the link between categories and subcategories from the results of open coding. At this stage, the researcher is able to draw up a diagram and see the interrelationships between categories according to the group. Selective coding is the final stage to integrate and refine theory (Strauss \& Corbin, 1998) from the results in order to draw conclusions from the overall research results and conclusions per category group. The data category groups were presented by the team in the form of themes of results and research discussions.

\section{Result and Discussion}

\section{Development of Financial Position}

Since the implementation of PP No. 71 of 2010, all government accounting entities, including local governments, are required to prepare financial reports every year. The financial report that must be prepared is the Budget Realization Report, presenting the budget and the realization of regional revenues and expenditures in one fiscal year. The Balance Sheet presents the position of regional assets in the form of current assets, fixed assets, intangible assets, and other assets which are the rights of the regional government. In addition, the liability position and equity position at the reporting date are also presented. Operational Report, presenting accrued income and expenses of government accounting entities in one period. In addition, a report of excess budget balance and a report on changes in equity is also presented, a cash flow statement and notes to financial statements.

Wrong one consequence of the application of PP No. 71 of 2010 is the application of the accrual basis in the preparation of government financial statements. Accruals will make the government more transparent, especially in the management of costs and revenues. So that the quality of the information presented as the basis for decisionmaking increases (Blondal, 2003). Financial reports are of higher quality because the public can find out the position of state assets, liabilities, and equity in certain positions.

One form of accountability and transparency that has been implemented by the Indonesian government is through the publication of financial reports. The audited central government financial reports can be accessed by bk.go.id. BPK as the government's external auditor agency is also very accountable and transparent for its audit results. So that the public can freely access audited financial reports and audit reports.

Revenue is often the first focus to assess the financial condition of an organization. The development of central government revenues during the 2016-2020 period can be seen in Figure 1.



Figure 1 Revenue Development by Source

Source: bpk.go.id

Figure 1 shows that total state revenues continued to increase from 2016 to 2019 . The Covid-19 pandemic in 2020 also resulted in a decline in state revenues, especially for the taxation sector and non-tax state revenues. This happened because several sectors of the economy experienced a significant decline in income. Indonesia's income is still very much dominated by taxation sources, although there was a decrease of $16.88 \%$ from 2020 compared to the previous year. Positive tax growth only occurred in personal income tax (PPh Number. 25/29), the other main types of taxes experienced a decline. This reflects the high level of compliance and voluntary awareness of individual taxpayers. Sources of funds originating from non-tax state revenues have also decreased as a result of the Covid 19 pandemic. In 2020, the number of state revenues has increased from sources of funds originating from grants. The increase in grant revenue reached $242.58 \%$, mainly from grants related to the Regional Head Election and grants for the context of handling the Covid-19 Pandemic. In addition, there has also been an increase in the understanding and awareness of ministries and agencies to report grant revenues directly to the State General Treasurer. 
Government spending is also important information for stakeholders. The development of central government spending in 2016-2020 is presented in Figure 2.

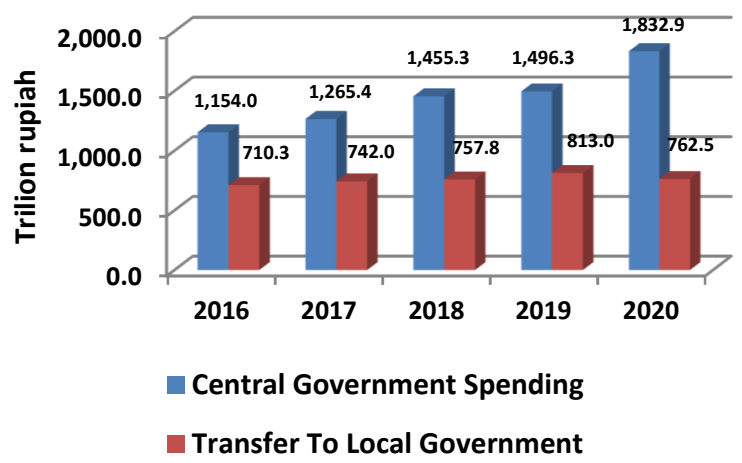

Figure 2 Development of Central Government Expenditure

Source: bpk.go.id

The central government spending group continues to increase every year. The types of expenditure in this group include personnel expenditure, goods expenditure, capital expenditure, grant expenditure, debt interest payment, social assistance expenditure, subsidy expenditure, and other expenditures. In 2020 there was a shift in budget allocations for several types of spending in the context of handling and preventing the Covid 19 pandemic in Indonesia. This budget shift does not only occur in the central government budget but also occurs at the local government level and other government agencies. Expenditures for transfers to regions decreased in 2020.

The government's financial condition can also be seen from the position of assets, liabilities, and equity. Figure 3 shows the development of the three groups of accounts for 2016-2020.

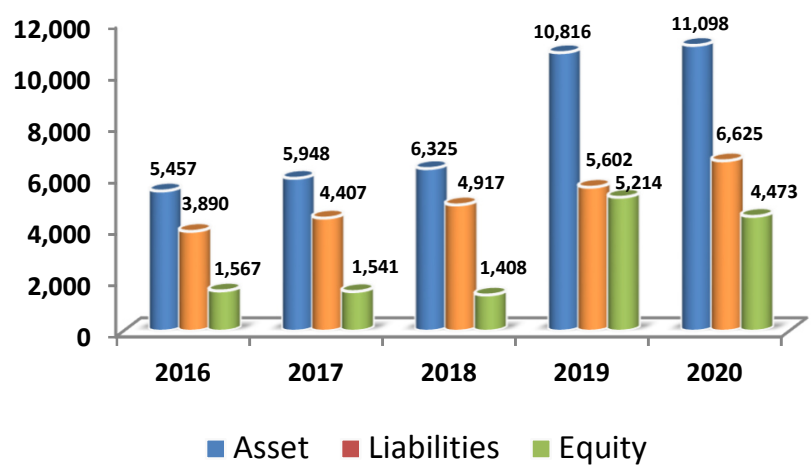

Figure 3 Development of Central Government Assets, Liabilities, and Equity

Source: bpk.go.id

Total assets continue to increase every year for the 2016-2020 period. The highest increase occurred in 2019 with total assets reaching Rp. 10,816 Trillion. The high number of assets must be optimized for good use. The utilization of assets, especially fixed assets, can be a source of income for the state. The government must pay attention to the use of assets, especially at the regional level. In addition, it must also pay attention to efficiency in the use of fixed assets (Tran \& Noguchi, 2020).

The government must also pay attention to the amount of increase in state debt which also increases from year to year. Indonesia's total sovereign debt in 2020 has reached more than $50 \%$ of total assets. This certainly has an impact on the number of debt interest payments which increased to $17.14 \%$ of total government spending in 2020. Central government equity experienced the highest increase in 2019 to reach $270.31 \%$. This increase occurred in line with the increase in government assets. However, in 2020 equity decreased by $14.21 \%$ compared to the previous year. One of the reasons for the decline was due to an increase in total assets of only $2.61 \%$, while there was an increase in the value of government debt by $18.26 \%$. Debt development, burden debt interest payments, and tax receipts can be seen in Figure 4. 


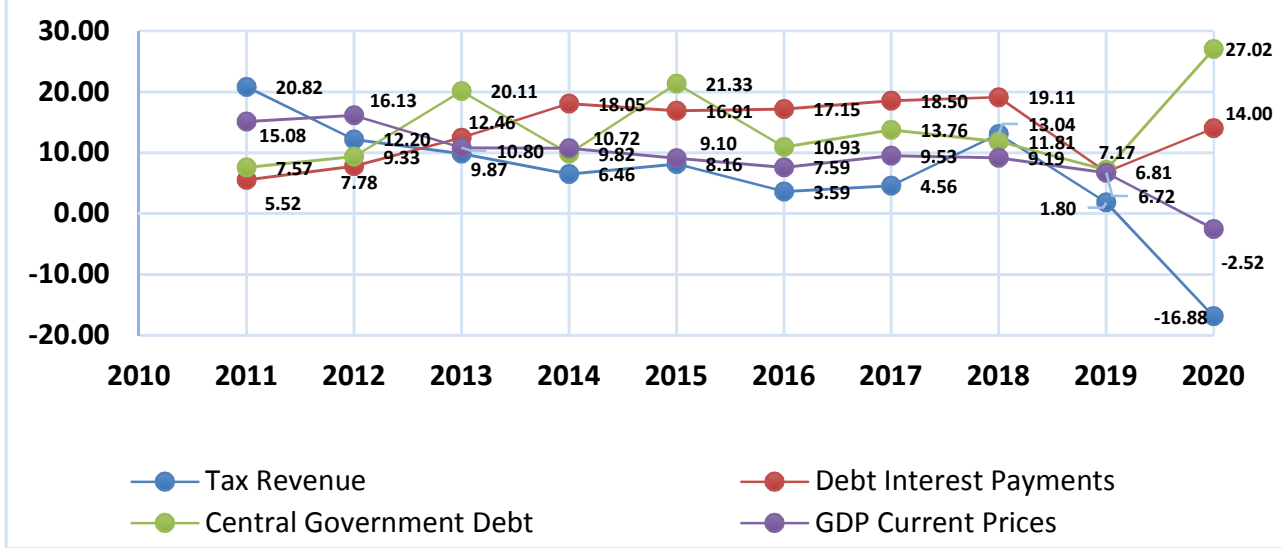

Figure 4 Trend of Changes in Government Debt, Interest Expense, Gross Domestic Product and Taxes 2011-2020 Source: bpk.go.id

Figure 4 shows the trend of total government debt during the period 2011-2020. Despite fluctuations in the percentage of government debt, the trend shows an increasing trend. The highest increase occurred in 2020, along with a fairly high decline in tax revenue. An increase in the amount of debt will have an impact on the direction of increasing the amount of debt interest payments. Debt interest becomes a fixed expense during the period of the debt period, which will be the burden of the state. Interest payments on debt are the third-highest after goods and personnel expenditures in the central government expenditure group.

\section{Development of Audit Opinion on Financial Statements}

BPK audits financial reports based on the 2007 State Financial Auditing Standards (SPKN). The audit results are presented in three books, namely book one consisting of the BPK audit report containing statements of opinion and audited financial statements, book two containing reports on audit results related to the system. internal control and book three containing reports on the results of inspections related to compliance with laws and regulations.

BPK's opinion consists of a standardized opinion, namely unqualified, which is given if the condition of the financial statements has been presented in accordance with Government Accounting Standards (SAP) and no material is found. BPK too can issue opinions other than the standard form, namely qualified, disclaimer, and adverse. An unqualified opinion is given if there is a condition that the overall financial statements have been presented in accordance with SAP and are free of material misstatement, except for certain accounts that are excluded in the independent auditor's report. Disclaimer is given if the auditor does not obtain confidence in the financial statements so that he cannot provide an opinion. One of the reasons is the limitation of movement and the acquisition of audit evidence while the auditor is in the field. Adverse opinion if there is a condition of incompatibility of the financial statements with SAP and there is a material misstatement. The opinion on the central government's financial statements from 2016 to 2020 is very good because it always gets unqualified. Although the unqualified opinion has been obtained, there are still some findings related to internal control and compliance. In 2018 there were 25 findings consisting of 19 internal control findings and 6 compliance findings. The number of these findings increased in 2019 to 31 findings. The results of the BPK audit revealed 26 findings related to internal control and 5 findings related to compliance. The BPK audit of the central government's 2020 financial statements contained 26 findings related to internal control and compliance. Findings on the central government's financial statements are distributed across several ministries and agencies.

Ministries and institutions are also accounting entities whose financial statements are also audited. The results of audits of the financial statements of ministries and agencies from 2014 to 2020 can be seen in Table 1 .

Table 1. Development of Opinion Gains on Financial Statements of Ministries and Institutions

The Year 2014 - 2020

\begin{tabular}{|c|c|c|c|c|c|}
\hline Year & Unqualified & Qualified & Disclaimer & Adverse & Description \\
\hline 2014 & 62 & 18 & 7 & 0 & 87 \\
\hline 2015 & 56 & 26 & 4 & 0 & 86 \\
\hline 2016 & 74 & 8 & 6 & 0 & 88 \\
\hline 2017 & 80 & 6 & 2 & 0 & 88 \\
\hline 2018 & 82 & 4 & 1 & 0 & 87 \\
\hline 2019 & 85 & 2 & 1 & 0 & 88 \\
\hline 2020 & 85 & 2 & 0 & 0 & 87 \\
\hline
\end{tabular}

Source: bpk.go.id.

The quality of the financial reports of ministries and institutions under the central government is getting better. This quality is evidenced by the continuous increase in the number of unqualified opinions obtained by ministries 
and agencies every year. In 2014 only 62 ministries and agencies managed to obtain an unqualified opinion. This number continues to increase every year, although it had decreased in 2015 . The highest achievement occurred for the financial statements of ministries and agencies in 2020, as many as 85 managed to obtain the highest opinion and only two ministries and institutions received qualified opinions.

Quality is also shown by the decreasing number of ministries and institutions that have received a disclaimer, even in 2020 no one has received this opinion. Appreciation must be given because from 2014 to 2020 none of the ministries and institutions received adverse events. This shows that there are no financial reports of ministries and institutions that are considered unreasonable. The number of ministries and institutions has changed due to changes in nomenclature, changed status, and new ones. So that there are variations in the number of ministries and institutions each year.

Obtaining an unqualified opinion is one of the performance targets for government agencies. The cause of the unqualified opinion is due to certain conditions. At the local government level, one of the causes of the failure to achieve an unqualified opinion is the issue of assets (Saougi, Rahayu \& Machfudin, 2018). The case findings from the results of the BPK examination certainly affect the financial management of local governments in Indonesia which is not going well (Effendy, 2013). Therefore, all findings must be immediately followed up by the auditee.

\section{What is the Condition of the Internal Control and Compliance?}

Internal control is a process, policy, and procedure designed by management to ensure reliable financial reporting and the preparation of financial reports in accordance with the applicable accounting framework (Tuanakotta, 2014). The four main objectives of an organization's internal control system are:

1. maintain organizational assets

2. ensure the accuracy and reliability of the organization's accounting records and information

3. improve organizational operating efficiency

4. measuring compliance with policies and procedures that have been established by management.

The implementation of an internal control system will be able to reduce and avoid fraud in the organization's financial management.

Table 2 shows several internal control issues at ministries and institutions based on the results of the BPK audit of the 2018-2020 Financial Reports.

Table 2 Internal Control Problems in Ministries and Institutions

\begin{tabular}{|c|c|c|c|c|}
\hline No & Description & 2018 & 2019 & 2020 \\
\hline 1 & Weaknesses of Accounting and Reporting Control Systems & 307 & 376 & 371 \\
\hline 2 & $\begin{array}{c}\text { Weaknesses of the Control System for the Implementation of the Revenue and } \\
\text { Expenditure Budget }\end{array}$ & 395 & 435 & 381 \\
\hline 3 & Weaknesses of Internal Control Structure & 199 & 226 & 232 \\
\hline
\end{tabular}

Source: bpk.go.id

Internal control issues related to financial reporting continue to experience a downward trend, except for the weakness of the internal control structure. In 2018 and 2019, the most problems were found for the weakness of the control system for the implementation of the revenue and expenditure budget, the weakness of the internal control structure being the lowest. This condition is different for 2020, the weakness of the accounting and reporting control system and the weakness of the control system for the implementation of the revenue and expenditure budget showed a decrease compared to the previous year. Even though it is still at its lowest position, the weakness of the internal control structure has actually increased compared to 2019.

Government regulations No. 60 of 2008 defines the Internal control system as an integral process for actions and activities carried out continuously by the leadership and all employees. The five elements of internal control include the control environment, risk assessment, control activities, information and communication, and monitoring. Of the five elements, the key to the successful implementation of internal control lies in the control environment. Leadership commitment is the main key in this first element.

Leaders who show high commitment will be role models for all members of the organization. The success of internal control of course requires support from all parties in the organization. Top management can only move the organization effectively if all parts of the organization also move together. A control environment that is created comfortable and conducive to work is the task of a leader. Organizational leaders must also pay attention to a mutually supportive organizational culture so that synergies between sections and between individuals can work well. Good leaders in government organizations are very important. Leaders who are role models for all members of the organization are not shown through statements or instructions, but examples will be better if shown through attitudes. The attitude of commitment to discipline from a leader will create a culture of shame for being undisciplined for other members of the organization. So that in implementing all elements of internal control, leadership commitment becomes very important, because government organizations have the task of serving the public interest. 
Compliance with laws and regulations is an obligation for all government organizations. This is one of the differences with private organizations. Binding regulations for government organizations can be more than private. This condition is reasonable because government organizations do not aim to earn profits, most of the revenue to carry out their activities comes from the community in the form of taxes and has a responsibility to maximize the welfare of the community. Non-compliance can have an impact on state losses, potential state losses, or decreased revenues. The results of the BPK audit also raised the issue of non-compliance. The problems of non-compliance with ministries and agencies for 2018-2020 are shown in Table 3.

Table 3 Problems of Non-compliance in Ministries and Agencies

\begin{tabular}{|c|c|c|c|c|}
\hline No & Description & 2018 & 2019 & 2020 \\
\hline 1 & Non-compliance Issues that may Result in Loss & 427 & 472 & 397 \\
\hline 2 & Non-compliance Issues that may Lead to Potential Losses & 43 & 48 & 46 \\
\hline 3 & Non-compliance Issues That Can Lead to Lack of Acceptance & 154 & 148 & 162 \\
\hline 4 & Administrative irregularities have no financial impact & 384 & - & - \\
\hline
\end{tabular}

Source: bpk.go.id

The problem of non-compliance that can result in losses is the highest among other types of non-compliance problems. The number of these problems decreased in 2020 but is still at the highest position. One of the BPK's recommendations for this non-compliance finding is to deposit or return it to the state treasury.

BPK does find internal control weaknesses and non-compliance issues every year. However, these findings do not materially affect the fairness of the presentation of the central government's financial statements. BPK continues to disclose these findings and provide recommendations for future improvements (bpk.go.id). Improvements based on the follow-up of the recommendations will be able to improve the problem of the condition of the financial statements.

\section{Strategy for Solving Problems in the Condition of Financial Statements}

The local government is obliged to account for all funds from any source it manages for the delivery of services to the community. Financial accountability results are communicated to stakeholders. The form of government financial accountability that is most recognized by stakeholders in government financial statements. Financial reports can be used to assess the financial condition (Ritonga, 2016) and financial health (Iqbal, Baga \& Dedi, 2017) of the government.

The BPK audit is an activity to check the quality of financial reports, the level of accountability, the implementation of internal control, compliance with standards, and various applicable regulations. An audit of the government financial statement is carried out annually. The audit results are stated in the audit report and opinion statement. Four levels of opinion are given from the audit results, namely unqualified, qualified, disclaimer an opinion, and not fair. In addition to opinions, BPK also has a target to continue to make improvements to the management of state finances. So that BPK always monitors the follow-up on the findings of the Audit process. According to the BPK Regulation Number 2 of 2017 concerning Monitoring the Implementation of Follow-up on the Recommendations of the BPK Examination Results, the results of the follow-up review are classified into 4 statuses, namely, first, follow-up was in accordance with the recommendations. Second, the follow-up was not in accordance with the recommendations. Third, the recommendations have not been followed up and finally, the recommendations cannot be followed up.

Accounting entities audited by BPK have 60 days to complete follow-up on findings. However, the reality is that the government is often unable to immediately complete the follow-up action. This is evidenced by the many findings of BPK as of June 30, 2021, that have not been followed up by various government accounting entities as presented in Figure 5.

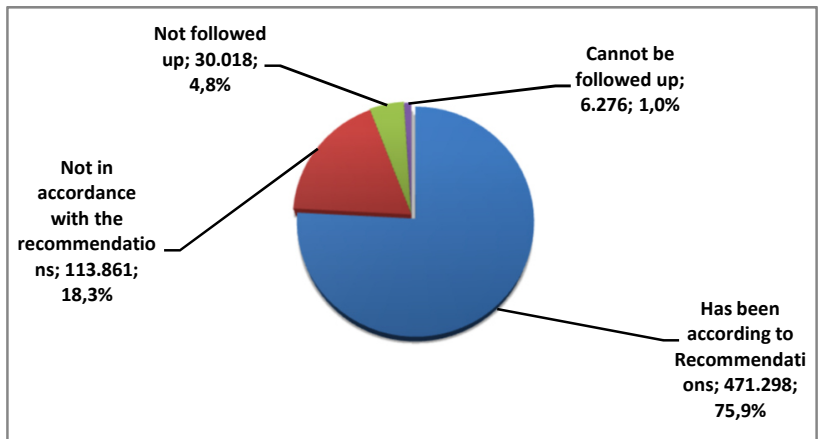

Figure 5: Monitoring results on the implementation of follow-up recommendations on audit results on BPK audit reports published for the period 2005 - Semester 12021

From Figure 5 it can be seen that there are still 30,018 findings that have not been followed up, 6,276 cannot 
be followed up and 113,861 findings have been followed up but not in accordance with the recommendations.

Completion of follow-up is very important for accounting entities including local governments because the findings will not be removed from the BPK's list of findings even though they are from an audit process that has been completed for years if they have not been followed up. The follow-up to BPK's findings, if implemented, is actually expected to have a positive impact on improving the entity's internal control system and increasing compliance with applicable regulations.

\section{Conclusion and Implication}

The position of the Indonesian government's revenue decreased in 2020 due to the impact of the Covid 19 pandemic. Government assets continued to increase. The highest increase occurred in 2019. Equity also experienced the highest increase in 2019. The government must also be aware of the increasing amount of liabilities because this has an impact on the burden of debt interest payments. The quality of the central government's financial reports is good when viewed from the acquisition of unqualified opinions since 2016-2020. Several problems are indeed found every year, both related to weaknesses in internal control and non-compliance with laws and regulations, but these problems do not materially affect the fairness of the financial statements.

The implications of this research result for the government for policy making proposals such as improving internal control and increasing compliance, especially those that can have an impact on losses, potential losses, or a decrease in state revenues. The limitation of this research is that it only conducts a study and analysis based on documents from audited financial statements and audit reports as well as an overview of audit results from the BPK. Further research can develop the results of this research with other methods such as using quantitative methods or other qualitative methods. The use of data from interviews and focus group discussions will further deepen the results of the study and obtain more comprehensive results.

\section{References}

Andrianto, J., dan Irianto, G. (2008). Akuntansi dan Kekuasaan (dalam Konteks) Bank BUMN Indonesia. Malang: Fakultas Ekonomi Universitas Brawijaya bekerjasama dengan Aditya Media Publishing.

Anggraini, Y., dan Puranto, B. H. (2010). Anggaran berbasis Kinerja: (Penyusunan ABPD secara Komprehensif). Yogyakarta: UPP STIM YKPN.

Berellson, B. (1952). Content Analysis in Communication Research. Glencoe III, The Free Press.

Blöndal, J. R. (2003). Accrual accounting and budgeting: key issues and recent developments. OECD Journal on Budgeting, 3(1), 1608-7143. https://doi.org/10.1787/budget-v3-art4-en

Badan Pemeriksa Keuangan (2018) Ikhtisar Hasil Pemeriksaan Semester I 2018, www.bpk.go.id

Badan Pemeriksa Keuangan (2019) Ikhtisar Hasil Pemeriksaan Semester II 2018, www.bpk.go.id

Badan Pemeriksa Keuangan (2019), Laporan Hasil Pemeriksaan atas Laporan Keuangan Pemerintah Pusat Tahun 2018, www.bpk.go.id

Badan Pemeriksa Keuangan (2020) Ikhtisar Hasil Pemeriksaan Semester II 2019, www.bpk.go.id

Badan Pemeriksa Keuangan (2020) Ikhtisar Hasil Pemeriksaan Semester I 2020, www.bpk.go.id

Badan Pemeriksa Keuangan (2020) Laporan Hasil Pemeriksaan atas Laporan Keuangan Pemerintah Pusat Tahun 2019, www.bpk.go.id

Badan Pemeriksa Keuangan (2021) Ikhtisar Hasil Pemeriksaan Semester II 2020, www.bpk.go.id

Badan Pemeriksa Keuangan (2021) Ikhtisar Hasil Pemeriksaan Semester I 2021, www.bpk.go.id

Badan Pemeriksa Keuangan (2021) Laporan Hasil Pemeriksaan atas Laporan Keuangan Pemerintah Pusat Tahun 2020, www.bpk.go.id

Brown, K., Waterhouse, J., dan Flynn, C. (2003) Change management practices Is a hybrid model a better alternative for public sector agencies? The International Journal of Public Sector Management, 16(3), 230241.

Christensen, T., dan P. Lægreid. (2014) Performance and accountability - a theoretical discussion and an empirical assessment. Public Organization Review 15 (2): 207-225. https://doi.org/10.1007/s11115-013-0267-2.

Creswell, J. W. (2012) Research Design: Pendekatan Kualitatif, Kuantitatif dan Mixed. Yogyakarta: Pustaka Pelajar.

DiMaggio, P. J., dan Powell, W. W. (1991) The iron cage revisited: institutional isomorphism and collective rationality in organizational fields. in w. w. powell dan $\mathrm{p}$. j. dimaggio (eds.), the new institutionalism in organizational analysis. Chicago and London: The University of Chicago Press.

Effendy Y. (2013) Tinjauan hubungan opini wtp bpk dengan kasus korupsi pada pemda di indonesia kajian manajemen keuangan pemerintah, hubungan antara masyarakat, pemerintah dan pemeriksa (auditor), Jurnal Manajemen \& Bisnis, 13(01), April

Gruening, G. (2001) Origin and theoretical basis of new public management. International Public Management Journal, 4, pp. 1-25.

Guess, G. M. (2005) Comparative decentralization lessons from Pakistan, Indonesia, and the Philippines. Public 
Administration Review, Mar/Apr, 65(2), pp. 217-230

Gunawan, I. (2013) Metode Penelitian Kualitatif Teori dan Praktik, PT Bumi Aksara, Jakarta

Harun, H., \& Kamase, HP (2012a). Accounting change and institutional capacity: the case of a provincial government in Indonesia. Australian Accounting Business and Finance Journal, 6(2), 35-50. https://doi.org/10.1016/j.cpa.2016.02.003

Harun, H., Van Peursem, K., \& Eggleton, I. (2012b). Institutionalization of accrual accounting in the Indonesian public sector. Journal of Accounting and Organizational Change, 8(3), 257-285. https://doi.org/10.1108/18325911211258308

Harun H., Yi A \& A.Kahar (2013) Implementation and challenges of introducing NPM and accrual accounting in Indonesian local government, Public Money \& Management, 33(5), pp. 383-388, DOI:10.1080/09540962.2013.817131

Iqbal. M., Baga. LM \& Dedi B.H., (2017) Formulation design of fiscal health performance assessment and regional financial management (case study of west Java Province), Journal of BPPK, 10 (1), pp.11 - 23

Mahmudi (2016) Akuntansi Sektor Publik, First Edition, UII Press, Yogyakarta

Meyer, JW, \& Rowan, B. (1977). Institutionalized organization formal structure as myth and ceremony. American Journal of Sociology, Vol. 83, No. 2 (Sep), 340-363.

Patrick. H., (2012) Legitimacy in institutional theory: Three essays on social judgments in a globalized world, Posted at the Zurich Open Repository and Archive, University of Zurich, ZORA URL: https://doi.org/10.5167/uzh-72272, Dissertation

Polidano, C. (1999) The new public management in developing countries. IDPM Public Policy and Management, 13(November), pp. 1-38.

Puspawati, AA (2016). Implementation of new public management (NPM) in Indonesia bureaucracy reform, decentralization, public and private cooperation in improving public services), Journal of Publication, 1(1). pp. 38-53

Rahayu, S, (2016) Institutionalization process of SOA funds budgeting at basic education institutions in Indonesia. Research Journal of Finance Accounting, 7(4)

Rahayu, S., Yudi \& Rahayu (2021) The comparison of local government financial health, Research Journal of Finance and Accounting. www.iiste.org, Vol.12, No.14, pp. 66-75

Ritonga, I. T, Clark, C., \& Wickremasinghe, G. (2012). assessing financial condition of local government in Indonesia: an exploration. Public Municipal Finance, 1(2), 37-50.

Ritonga, I. T, (2016) Analisis Laporan Keuangan Pemerintah Daerah. Yogyakarta: UGM Press

Saougi, T, Rahayu, S dan Asep M, (2018), Analisis temuan pemeriksaan bpk ri atas aset tetap pada laporan keuangan pemerintah Kabupaten Merangin, pemerintah Kabupaten Tanjung Jabung Barat, pemerintah Kabupaten Tanjung Jabung Timur pada tahun Anggaran 2014 - 2016, Jurnal Akuntansi dan Keuangan, 3, Juli-Sept.

Selznick, P. (1996). Institutionalism "old" and "new". Administrative Science Quarterly, 41(2), pp. $270-277$.

Strauss, A., \& Corbin, J. (1998). Basics of Qualitative Research: Techniques and Procedures for Developing Grounded Theory. Thousand Oaks, CA: Sage Publications, Inc.

Tolofari, S. (2005). New public management and education. Policy Futures in Education, 3(1), pp. 75-89.

Tran T.V. \& Noguchi M. (2020): Public efficiency in Tokyo's metropolitan local governments: the role of asset utilization and budgeting, Public Money \& Management, DOI: 10.1080/09540962.2020.1734315

Tuanakotta. T.M. (2014). Audit Berbasis ISA. Salemba Empat Jakarta.

Yuwono, S., Utomo, DC, Zein, S., \& Azrafiany. (2008). APBD dan Permasalahannya (Panduan untuk Manajemen Keuangan Daerah). Malang: Bayu Media. 